Community Green Economic Development by leasing and utilizing Government Jurisdiction Ponds by Grameen Fisheries and Livestock Foundation in Bangladesh

\author{
Rouf, Kazi Abdur \\ Visiting Scholar, University of Toronto (rouf.kazi@utoronto.ca) \\ Associate Professor, Noble International University, USA
}

Received: 9 February 2014 Available Online: 1 June 2014
Revised: 29 May 2014 DOI: $10.5861 /$ ijrsm.2014.719

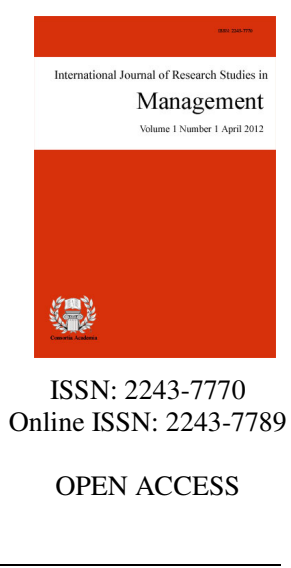

\title{
Abstract
}

Grameen Fisheries and Livestock Foundation (GMPF)-is a sister organization of Grameen Bank (GB) involves in livestock and fish culture, mobilizing poor people engage in livestock and fish production, agriculture, horticulture, homestead gardening, social forestation and bio-gas plants and other community green income generating economic activities to bring improvement in the quality of life of the poor, in particular of poor women. GMPF is managing leased of 1035 Khas (public) ponds having 2557.3 acres of water bodies and 20 fish seed farms leased from the Government of Bangladesh (GoB) for 25 years. The objectives of this study is to examine the policies, strategies and approaches of GMPF community economic development (CED) and to link CED concept with GMPF activities if it benefits to local poor people in Bangladesh. The study research questions are is Grameen Motsho O PashuSampoad Foundation (GMPF) a CED program in Bangladesh? If so, how it works, what approaches and strategies it follows, what are challenges it faces in implementing its programs in Bangladesh. The author writes this paper from his pre-and post-GMPF working experience. The paper contains author's live experience, review literature, secondary data and interpretative method of analysis.

Keywords: Community Economic Development (CED); Fish culture and Livestock services; social business 


\section{Community Green Economic Development by leasing and utilizing Government Jurisdiction Ponds by Grameen Fisheries and Livestock Foundation in Bangladesh}

\section{Introduction}

This paper is an overview of Grameen Motsho (Fisheries) O Pashusampad (Livestock) Foundation (GMPF), which is an example of the community resource asset-based [ponds community economic development (CED) project in Bangladesh. The paper examines applications of theories of CED as a strategy for improving the quality of life of marginalized people through GMPF activities in rural Bangladesh. The Grameen Motsho (Fisheries) O Pashusampad (Livestock) Foundation (GMPF) is a green social business community economic development project serving marginalised people in Bangladesh. The geographical areas of this project is in Bangladesh are covering 14 districts, 32 Thanas/sub- districts. The districts are Tangail, Sirajgong, Pabna, Bogra, Gaibandha, Rangpur, Kurigram, Nilphamari, Dinajpur, Thakurgaon, Panchaghar, Satkhira, Chittagong and Cox's bazaar, Satkhera and Jamalpur. GMPF involves in livestock and fish production, mobilizing poor people, engage in livestock and fish production, community forestation and other community green economic activities by managing leased 1035 Khas (public jurisdiction public) ponds having 2557.3 acres of water bodies, 20 fish seed farms lease of for 25 years (GMPF annual report 2006) from Government of Bangladesh (GoB) in 1986 (GMPF annual report 2006). It introduced two tiers accounting system that prevents project leaking and corruptions. It runs the project with 'no loss' principle. GMPF generates revenues from selling fishes, fingerlings and supply livestock vaccines. The profit generated from the project reinvested for ponds renovations, roads construction, and repair and project development.

GMPF is a social business institution generating revenues and serving poor people by utilizing these leased Khas ponds in Bangladesh. The GMPF connects local poor people to these ponds; involve them in livestock and fisheries activities. These livestock and fisheries activities open local green economic opportunity for marginalized communities there. In addition to these, GMPF encourages local poor people to form fish culture and livestock associations in order to develop their capacity building to manage these Khas ponds and to develop their partnership capacity and confidence among the beneficiaries. This asset-based community green economic development project generates the power of local fish and livestock production associations to drive the community green economic development process and leverage entitlements to local poor people (Mathieu \& Cunningham, 2004) for their own benefit.

\subsection{Objectives of the Study}

The objectives of this study is to examine the motives, policies, strategies and approaches of GMPF community green economic development (CED) and to link these concepts with GMPF if it benefits to local poor people in Bangladesh.

\subsection{Research Questions}

Is Grameen Motsho (Fisheries) O Pashusampad (Livestock) Foundation (GMPF) a CED program in Bangladesh? If so, how it works, what approaches and strategies GMPF follows. What are its strengths and challenges it faces in implementing its CED mission?

\subsection{Methodology}

The author writes this paper from his pre-and post-GMPF operation experience in Bangladesh. The author collected GMPF annual reports and other GMPF reports from GMPF office at Dhaka. The paper contains literature review and secondary data. He directly talks with GMPF executives, field officers, and local elites of 
the project to know about GMPF activities, policies, strategies and approaches in Bangladesh. The author looks at GMPF 'Memorandum of Articles' and 'Memorandum of Associations' and GMPF lease agreement with the Department of Fisheries and Livestock, Government of Bangladesh. The paper follows interpretative method; however, it does not critically analyze GMPF activities, outcomes, strengths and weaknesses. Therefore, this paper is not an analytical paper rather it is an informative paper that provides readers with a synopsis of community managed Khas ponds contributed to local poverty reduction, fish culture and livestock production, green technology transfer among marginalized people in Bangladesh.

\section{Literature Review}

Community economic development (CED) means a process through which citizens take charge of planning and managing economic development projects in their community areas with the aim of creating employment for them, improving their quality of life and developing greater community autonomy (Shragge, 1997, p. 103). It is an attempt to democratize the economic life of the neighborhood's particularly marginalized people. Quarter et al. (2009) believe that CEDs are working for communities that are facing problems; unemployment, poverty, job loss, environmental degradation and loss of community control, need to be addressed in a holistic and participatory way (p. 95). CED initiatives embrace the distinctive characteristics of a strong social mission, but earn revenues from the market and require ongoing external supports, often from government (Brown \& Iverson 2004; Dees, 1998; Quarter, Mook, \& Armstrong, 2009; Yunus, 2007). It refers to communities of common interest. CED programs can be considered as commercial non-profits. For example, CED- Canada emphasizes distinct values: it has emerged as an alternative to conventional approaches to economic development. In Canada there is an apex CED organization called Canadian Economic Development Network (CCEDNet) (Quarter, Mook, \& Armstrong, 2009, p. 80).

According to CEDNet CED defined as action by people locally to create economic opportunities and enhance social conditions in their communities on a sustainable and inclusive basis, particularly with those who are most disadvantaged. Putnam (2000) refers to these dynamics as social capital development, social engagement, trust, and informal cooperation, as social capital can create multipliers, as strong communities pull together and initiate new projects. Therefore, CED projects have an important role in reducing the hardships associated with social inequalities. CED projects are mainly targeting below average standard of living people or involve groups who experience extraordinary challenges. Many community scholars think CED is a tool used to get economic equality. It is a program to address economic insecurity of the marginalized members of the community.

Government supported CED projects, either direct full funding or partial funding to CED projects, or lease/donate government properties like ponds, lands, bazaars, roads, public busses, industries to community organizations, can generate revenues from them, covers project costs and contribute to local living green economics. The author believes that community green economic development projects are social businesses that are not completely dependent on external continuous support rather it generates revenues from its products and services to cover project costs. Moreover, inclusion of marginalized people in project services could generate employment among disadvantaged people; get green economic and social benefit from CED services. According to Quarter et al. (2009) CED involves organizations-nonprofits and cooperatives that are within social economy. These organizations earn a portion of their revenues from the market, sometimes in competition with other private sector firms, but they rely on support from government, and at times from corporations and individuals, both financial and volunteer labor. One of the intentions of CED project is reducing external funding/ public funding and ultimately reaching financial sustainability in order to be self-sufficient of its own after certain time. However, it is difficult for CED to survive as profit making business in the free market economy.

As CED project synchronize economic and social missions together in its social business model, CED project required ongoing external support for a while, but here the problem is external funding support decrease even funding support stopped before CED projects reach their financial self-sufficiencies. In Canada and USA 
government agencies and foundations are important supporters of CED projects although now government support is decreasing. Quarter et al. (2009) suggest that small business development funding could include CED initiatives in social businesses. Other alternatives could be private and CED project resource partnership sharing; public funding, foundations and community organizations collaboration project in the poverty prone area to generate employment among local disadvantaged people. In Canada government initiated and supported many aboriginal businesses and projects in Northern regions through the department of Indian and Northern Affairs Canada, and Aboriginal Businesses Canada (ABC).

Moreover, Community Futures Development Corporation (CFDCs) has 268 CED projects across Canada. These are community development corporations (CDCs) and public sector non-profits agencies that have social economic contribution in Canada. They are the social economy organizations that have market orientation that combine a social mission and vision. They serve small and medium businesses within the communities. For example, Quint Development Corporation serves five neighborhoods of Saskatoon through renting 45,000 square feet Community Enterprise Centre that combine retail and commercial office spaces. It also built housing cooperatives for ninety families including child care center, family recreation and community gardens (Quarter, Mook, \& Armstrong, 2009). These are outreach programs and services within their jurisdiction, which could be difficult in centralized public institutions.

Author's experience finds that projects like the technical and vocational training assistance program, agricultural projects, urbane food security services, community gardens, community kitchens, community transport pool services and community printing press could help community unemployed people to work in these projects and learn technical and vocational skills to make them employable in the job market. Therefore CED is a system of human activity directed to meeting human wants that is determined by deliberate allocations of scarce resources, including human time (Boothroyd \& Davis, 1993, p. 230). Here people gain confidence when their opinions and experience are valued; their confidence strengthens their participation in community planning and decision making (Shragge, 1997, p. 46). Therefore CED agencies should be organized to promote cooperation rather than competition although they operate in the free market economy. Through this process, community people are concerned with each other's well-being and gain satisfaction from cooperating. GMPF is an example of community economic and social/emotional project where people feel connected with each other although the purpose of this project is to increase community livestock and fish production and increase income, solidarity, distribute justice and enhance quality life among GMPF beneficiaries. Through GMPF-CED activities, services and processes it helps community marginalized members become empowered to participate in the community resource optimum uses, engage in community planning and decision making for the well-being of their own in the project areas.

According to Mathieu \& Cunningham (2004) this asset-based community development project could foster inclusive participation, fostering community leadership, foster relocation of power to communities and increase civic engagement in the community. It provides the source of constructive energy in the local communities. However, ideal community equality achievement is still hard to achieve in neoliberal market economy particularly in Bangladesh. Under community economic development, it is seen as synonymous with promoting growth in jobs, income, or business activity. Here community is seen simply as the locality in which businesses get together to promote their interests through economic expansion (Alexander, 2000; Quarter, Mook \& Armstrong, 2009).

Many local green jobs are created by CED projects by expanding/ creating green small-businesses like agricultural and artisan jobs. It increases local control and brings local living green economics' stability in the community. Moreover CED encourages local control and power ownership of resources; it creates organizations that are representative of and accountable to the local community, enables communities to address issues of poverty and inequality, environmental degradation and drives to basic social change (Shragge, 1997). Because CED principle is to utilize local resources, promote establishment of new green firms by local entrepreneurs and increase the productivity of the firms. Although CED approach is a single minded economic 
growth-commercialization approach and unable to structural change, CED projects increase the flow of money into local community. It has trickledown effect that helps the entire economy, which is very important to increase income among poor people and to address the issue of poverty. However, CED projects needs diversify external investment resources and use community resources, but it could reduce dependence on outside decision-makers by increasing local control over resource management. Moreover, community project initiators need to emphasis on planning for all relevant private, public and community agencies in setting targets, surveying opportunities and developing a wide range of strategies, which are sometimes absent in CED projects.

Although social enterprises, community green economic development programs/servicers, public sector non-profits, non-profit mutual associations, civil society organizations, cooperatives, credit unions, micro-credit agencies and social financings all are social businesses and they are components of social economy, they are different in terms of approaches, structures, designs, strategies and policies. All these organizations have both social and economic missions, but all of them have different principles and operate strategies in the market economy. However, they have common provision for generating revenue from their operations in addition to social well-being services to disadvantaged people. They are all different from charitable grants and relief organizations. Charitable organizations have traditions of social handout giving assisting those in need. Social enterprises are completely different from for-profit business organizations because for-profit business organizations main objective is profit maximizing; they don't have social and environmental commitment to society. In GMPF social businesses organization community members are not handout receivers rather they are community beneficiaries who are part of community fisheries and livestock production economic actors and social actors in Bangladesh.

Boothroyd and Davis (1993) think that community development corporation institutions favor those most in need in the community. This approach includes production and distribution based on non-market principles of common ownership, mutual aid, and improving productive life at the expense of the efficiency. It creates alternatives to capitalism, rebuild and reconnect people with water, air, soil, agriculture and changes the quality of life for a number of people; however, it requires a major shift in power which is usually not easy for local communities. Moreover, this entrepreneurial approach generally reinforces individualist and capitalist values, bringing poor people into competitive market economy (Shragge, 1997) that confirms by Jim Lotz (1987) community economic development research in USA.

\subsection{Author's involvement with GBJMF before and after inception of Grameen Bank Joysagore Motsho Farm}

On December 09, 1984, Muhammad Yunus, Managing Director, Grameen Bank (GB) Bangladesh requested the author to visit Government managed Nimgashi Fish Culture Project (NFCP), Sirajgong on his way return to Dhaka from Rangpur Grameen Bank branches tour. The author visited several Khas ponds of Nimgashi Fisheries Project (NFP) located in Raigong and Tarash Upzilla and collected preliminary information about NFCP. The NFP has huge infrastructures in Nimgashi and Tarash sub-districts. Many cluster Khas ponds situated in Nimgashi area. Among these Khas ponds, Joyshagore Digi (pond) is the biggest one in the area with 22.35 ha of water surface. Mahango tribal people, 20\% (approximately) of total population, live in this area; however, public has no access to these Khas ponds for fish cultivation although many poor people live on these ponds' embankments. Many rural powerful elites illegally occupied many Khas ponds and take benefit from them. Although many government officers work in this project, few of them stay in the project area. There is an excellent fish fingerlings production center in Nimgashi; however, it is in underproduction. The author's preliminary observation reported to Muhammad Yunus and to GB executives.

After one year (November 7, 1985) Yunus again sent the author to NFCP to survey it. At this time the author surveyed NFCP with GB another officer to explore the project resources and to asses if Grameen Bank and poor people could benefit from the project by managing it. The author writes a feasibility report on NFCP and identifies problems, potentialities, possibilities, and challenges for GB if GB is managing these Khas ponds and other resources of NFCP. 
On March 20, 1986 the author returned to Dhaka after delivering 5000 Thai Camble baby ducks to GB branches in Tangail and Dhaka district, managing director of GB request him to join GB Nimgachi Area Office as an Area Manager in order to start Grameen Bank micro-credit services in Nimgashi and its surrounding area. The author worked in Nimgachi for two years as an area manager. During this time he opened GB twenty Grameen Bank branches. In addition to his GB responsibilities he was involved with Grameen Bank Joysagar Motsho Project (GBJMP) operations in Raigonja, Tarash, Handial and Vangura sub-districts. He intensively traveled in each village of these sub-districts, visited all ponds of the projects, talked with rural elites, politicians, general people and government officials. He friendly explained them the missions and visions of GB and GBJMP in these sub-districts. Although at the beginning many rural elites were protested against GBJMP, later they were impressed of GB activities and appreciated GB and GBJMP activities in their area.

\subsection{Grameen Bank operation starts in Grameen Bank Joygagor Motsho Project (GJMP) in Khas ponds in}

\section{Sirajgong, Pabna and Dinajpur}

The Ministry of Fisheries and Livestock (MoFL), Govt. of Bangladesh (GoB) first transferred 782 ancients and derelict ponds with 675 ha water areas for 25 years to Grameen Bank in March 07, 1986 with the aim of improvement/better fisheries production and management, stop leaking/ corruptions by the government officials and to stop illegal occupancy of Khas (public jurisdiction) ponds by the local elites. Latter the government also decided to lease many other fish and shrimp farms and Fish Seed Multiplication Farms, spread over across Bangladesh. The Ministry of Fisheries managed Dinajpur Fisheries Project and Fish Seed Multiplication farms were handed over to Grameen Bank at the end of 1986. There were agreements between Government of Bangladesh and Grameen Bank for handing over physical possession of all assets and ponds on long term lease for community based management by organizing the landless poor people living on and rescue ponds those are occupied by locally influential people and around the embankments of the ponds. After receiving them, GB renamed this project to Grameen Bank Joysagore Motsho Project (GBJMP) in 1987. In 1994, GBJMP became a separate organization and named it Grameen Motsho Foundation (GMF). It again renamed Grameen Motsho O Pasusampad Foundation (GMPF) in 1999.

The author was assigned to attend all 'GBJMP Advisory Committee' meetings in addition to his job in Grameen Bank Training, Research and Special Program portfolio at Dhaka. Although at the beginning the local elites protested against of GBJMP management, GBJMP is able to overcome this problem and smoothly run the project. The primary objective of GMPF is to produce and to provide protein rich food and thus improve human dietary standard. GMPF other objectives are (1) to undertake production, transportation, processing and marketing of products of fisheries, livestock, agriculture, horticulture, homestead gardening, social afforestation and bio-gas plants and other income generating activities to bring improvement in the quality of life of the poor, in particular of poor women; to finance, assist, take or give on lease, or otherwise support the management of fisheries, livestock, horticulture and forestry-based enterprises which are owned by the poor, in particular by poor women. (2) to promote the increased participation of women in fisheries, livestock, horticulture and forestry production, storage, marketing, processing and other such related business; and (3) to promote the increased participation of women in integrated fish-crop-livestock, horticulture, bio-gas, milk cooling, feed making and forestry production, storage, processing, marketing, and other related business.

The goals of GMPF are: diversifying rural production, increasing employment potentials, to provide alternative employment to rural people especially women, produce more fish, livestock and horticultural products for local consumption and to improve the nutritional standards in rural areas through additional supplies of animal proteins and vitamins, raising the net income of the rural communities, alleviation of poverty and increasing opportunities for earning foreign exchange and ensuring sustainable livelihood of the marginalized people in Bangladesh.

GMPF had many programs that are operated through (1) Fisheries Management and Aquaculture, (2) Livestock Dairy Development and Social Forestry, (3) Social Mobilization Technical Assistance Consultancy 
and NGO Execution, (4) Training Human Development and Research and Development (R \& D), and (5) Planning, Monitoring and Evaluation. The GMPF has its training institute Joysagar named Joysagar Training Institute. GMPF had five farm managers at Joysagar Mostsu Farm, Dinajpur Farm, Jamiuna Borrow-pit Farm, Chokoria shrimp Farm and Satkhira shrimp Farm. GMPF had officers for empowerment of Coastal Fishing Community Project, Community Livestock Officers, Veterinary Surgeon, program organisers and community organisers for mobilizing community people for fisheries and aquaculture and livestock development. The GMPF had provided micro-credit to fisheries farmers and livestock farmers by its credit field assistants.

\section{Functions/activities of Grameen Motsho O Pashu Sampsad Foundation (GMPF)}

The functions /activities of GMPF are as follows:

> Community Fisheries Development: Fish farming, Shrimp farming, integrated aquaculture, fish mono culture, fish poly culture, fish-cum-shrimp culture, paddy-cum-fish culture, duck weed culture, fish hatcheries and nurseries, shrimp hatchery, brood management, marketing of fish, hatchlings \&fry, Ice making and net-making.

> Community Livestock and Diary Development: Cow farming, milk chilling, processing and marketing, beef fattening, goat farming, poultry farming, duck farming, pig farming, use of cow dung as slurry and fertilizer, development of bio-gas plants, community diary enterprises and community feed mills.

$>$ Community Farming and Social Afforestation: Social forestry, home-stead gardening, landscape gardening, horticulture farming, crops \& fodder farming, and plant nurseries.

> Training and Manpower Development: Programs include training of GMPF officers \& staff, training of government and NGOs staff, training of group members, international training on social mobilization, groups and community development through integrated fish-crop-livestock and dairy development activities.

> Social Mobilization Program: This program includes motivate and orientation, formation of groups and centers, facilitation and communication skill development, gender awareness, legal awareness, awareness building for health, nutrition, safe water \&sanitation, education and rights, training of poor men and women on facilitation and communication skill development, training on social mobilization and gender issues, group and community development, training on fisheries, livestock, social afforestation, horticulture and homestead gardening etc. (Memorandum of Articles and Memorandum of Association (GMPF), 2003; Memorandum of Articles and Memorandum of Association (GMF), 1994).

\subsection{Joysagor Aquaculture Farm}

The Nimgachi Fish Culture Project named as Joysagor Fish Farm (JF) by Grameen Bank after the name Joysagor-the biggest pond in the area with 22.35 ha of water surface. JF is scattered over 200 square kilometres of remote rural areas of 5 Thanas of Sirajgong, Panba and Bogra districts where ancient ponds of Paul and Sen Dynasties were left derelict and unused for hundreds of years. This has rendered these ponds as grazing grounds of cattle and goats. For rehabilitation and aquaculture, GB transferred these resources to Grameen Motsho (Fisheries) Foundation (GMLF) soon after its creation in 1994 as its sister concern. GMLF organised the local people living on banks of the ponds or its close vicinity, formed them into groups of five beneficiaries and centers of 6-8 groups who were trained in aquaculture, rural development and social development activities and were given all inputs including fry, fertilizers, manure, feeds, nets, boasts, etc. The possessions of the derelict ponds were given over from the vested interest groups to the down-trodden and resource less poor. It was an uphill task. GMPF has excavated/re-excavated 432 ponds with 417.50 ha water area and brought under scientific fish culture (GMPF, 2006). Table-1 shows year wise performance of Joysagar Farm. 
Rouf, K. A.

3.2 JF year-wise fish production, share and income of beneficiaries

A total of 14451.22 MT of fish were produced by JF since inception up to 2006. Fifty percent of the fish went to the share of poor beneficiaries. An amount of Tk. 179.21 million was received by the beneficiaries in 16 years as their share. Number of beneficiaries rose from 2249 in 1990-91 to 5876 in 2006. Per capita additional income through fish culture rose from TK. 1700 in 1990-1991 to Tk. 7223 in the year 2006. Per ha fish production rose from $700 \mathrm{~kg}$ in $1988-89$ to $2734.30 \mathrm{~kg}$ in 2006 -a rise of over 3905 in last 20 years or $19.53 \%$ per annum increase on an average. Out of 5876 of VGMs 2756 were involved in fish culture in 2006 (Grameen Mostsho O Pashusampad Foundation Annual Report 2006).

Table 1

Year Wise performance of Jaysagor Farm (JF)

\begin{tabular}{|c|c|c|c|c|c|c|c|c|c|}
\hline Year & $\begin{array}{c}\text { \# of } \\
\text { ponds } \\
\text { under } \\
\text { cultivatio } \\
\text { n }\end{array}$ & $\begin{array}{l}\text { Water } \\
\text { area } \\
\text { (ha) }\end{array}$ & $\begin{array}{l}\text { Producti } \\
\text { on of } \\
\text { fish } \\
\text { (MT) }\end{array}$ & $\begin{array}{l}\text { Prod. } \\
\text { Of } \\
\text { fish } / \mathrm{ha} \\
(\mathrm{kg})\end{array}$ & $\begin{array}{l}\text { Prod. Of } \\
\text { hatchlings } \\
\quad(\mathrm{kg})\end{array}$ & $\begin{array}{c}\text { Total } \\
\text { income } \\
\text { Tk. In } \\
\text { Lacs }\end{array}$ & $\begin{array}{c}\text { Share of } \\
\text { beneficiaries } \\
\text { @ 50\% (Tk. } \\
\text { in Lacs) }\end{array}$ & $\begin{array}{c}\quad \# \\
\text { benefic } \\
\text { iaries }\end{array}$ & $\begin{array}{c}\text { Av } \\
\text { income } \\
\text { /head - } \\
\text { Tk. }\end{array}$ \\
\hline 1986-87 & 185 & 225.20 & 157.0 & 700.0 & 193.2 & 12.9 & - & - & - \\
\hline $1987-88$ & 306 & 335.37 & 160.0 & 477.1 & 122.9 & 40.1 & - & - & - \\
\hline $1988-89$ & 356 & 399.06 & 173.0 & 433.5 & 142.9 & 48.1 & - & - & - \\
\hline $1989-90$ & 347 & 389.37 & 237.0 & 608.7 & 190.9 & 58.9 & - & - & - \\
\hline $1990-91$ & 388 & 404.48 & 456.0 & 1127.7 & 240.8 & 66.0 & 38.2 & 2249 & 1700 \\
\hline $1991-92$ & 392 & 382.98 & 503.0 & 1313.4 & 279.9 & 60.6 & 46.0 & 2301 & 2000 \\
\hline $1992-93$ & 392 & 382.98 & 810.0 & 2115.0 & 425.6 & 197.9 & 86.2 & 2165 & 3980 \\
\hline 1993-94 & 396 & 386.16 & 920.0 & 2382.4 & 656.0 & 190.6 & 78.4 & 2198 & 3566 \\
\hline 1995 & 396 & 386.16 & 968.0 & 2506.7 & 624.3 & 241.4 & 103.4 & 2247 & 4600 \\
\hline 1996 & 397 & 386.83 & 986.0 & 2548.9 & 633.0 & 221.7 & 94.2 & 2247 & 4200 \\
\hline 1997 & 406 & 393.52 & 867.0 & 2203.2 & 551.6 & 222.3 & 97.1 & 2322 & 4200 \\
\hline 1998 & 421 & 401.55 & 621.6 & 1548.1 & 560.9 & 198.8 & 85.6 & 2293 & 3733 \\
\hline 1999 & 423 & 411.00 & 842.7 & 2050.7 & 504.6 & 269.0 & 121.3 & 2548 & 4760 \\
\hline 2000 & 427 & 415.52 & 869.2 & 2091.8 & 552.3 & 292.7 & 125.4 & 2628 & 4770 \\
\hline 2001 & 427 & 418.27 & 907.7 & 2193.1 & 569.1 & 313.7 & 137.7 & 2724 & 5057 \\
\hline 2002 & 427 & 415.52 & 987.1 & 2304.8 & 645.9 & 330.3 & 148.6 & 2776 & 5351 \\
\hline 2003 & 430 & 415.74 & 950.1 & 2285.4 & 612.3 & 328.4 & 142.3 & 3128 & 5218 \\
\hline 2004 & 430 & 415.78 & 881.8 & 2120.9 & 709.9 & 326.6 & 133.2 & 3855 & 4832 \\
\hline 2005 & 432 & 417.5 & 1012.4 & 2420.1 & 739 & 381.9 & 155.5 & 4674 & 5582 \\
\hline 2006 & 432 & 417.5 & 1141.6 & 2734.3 & 818 & 496.7 & 199.1 & 5876 & 7223 \\
\hline Total & - & - & 14451.2 & - & 9773.1 & 4298.7 & 1792.1 & - & - \\
\hline
\end{tabular}

Source. Grameen Mostsho O pashusampad Foundation Annual Report 2006

\subsection{Dinajpur Farm (DF)}

Dinajpur Farm (DF) was taken over from the DoF of GoB during 1987-1988 with 65 ponds having 155.46 ha of water areas scattered over the remotest rural areas of the greater Dinajpur district presently the new three districts of Dinajpur, Thakurgaon and Panchaghar (Grameen Annual Report, 1987). Most of these ponds were excavated by the local kings/Zamindars about 500-800 years ago. Bangladesh's largest man-made pond 'Ramsagor Dhighi' with a water area of 30 ha is located about 10-km North of Dinajpur town. Out of these 65 ponds 51 ponds were brought under fish culture by organizing landless poor people of the area. Out of 1159 village group members (VGMs) 674 were involved in fish culture in 2006.

The DF production of fish during the period 1988-1989 was only 18.60 MT per ha, which increased to 260 MT in 2006. The income out of fish sales increased from tk. 4.79 lacs to k 92.60 lacs during 1988-2006. 400\% of the sale proceeds were given to the group members. Beneficiaries' per capita additional income was raised from Tk. 1340 in 1992 to Tk. 4911 in 2006. Per ha fish production rose from $210.55 \mathrm{~kg}$ in 1988-99 to $2437 \mathrm{~kg}$ in 2006 
Community Green Economic Development by leasing and utilizing Government Jurisdiction Ponds

- a rise of $1157 \%$ in last 18 years or $64 \%$ per annum on an average (Grameen Mostsho O pashusampad Foundation Annual Report, 2006).

Table 2

Year-wise performance of DF

\begin{tabular}{|c|c|c|c|c|c|c|c|c|}
\hline Year & $\begin{array}{c}\text { \# of } \\
\text { ponds } \\
\text { under } \\
\text { cultivatio } \\
\text { n }\end{array}$ & $\begin{array}{c}\text { Water } \\
\text { area (ha) }\end{array}$ & $\begin{array}{l}\text { Production } \\
\text { of fish } \\
\text { (MT) }\end{array}$ & $\begin{array}{c}\text { Production } \\
\text { of fish/ha }\end{array}$ & $\begin{array}{l}\text { Total } \\
\text { Income } \\
\text { (Tk. in } \\
\text { Lacs) }\end{array}$ & $\begin{array}{c}\text { Share of } \\
\text { beneficiari } \\
\text { es @ } 40 \\
\text { (Tk. In } \\
\text { Lacs) }\end{array}$ & $\begin{array}{c}\text { \# of } \\
\text { beneficiari } \\
\text { es }\end{array}$ & $\begin{array}{c}\text { Income } \\
\text { per head } \\
(\mathrm{Tk} .)\end{array}$ \\
\hline $1988-89$ & 35 & 88.34 & 18.60 & 210.55 & 4.79 & - & - & - \\
\hline $1989-90$ & 50 & 133.18 & 19.62 & 147.32 & 6.53 & - & - & - \\
\hline 1990-01 & 53 & 136.52 & 49.34 & 361.41 & 11.84 & - & - & - \\
\hline $1991-92$ & 53 & 140.81 & 96.34 & 684.18 & 15.10 & 6.04 & 451 & 1340.00 \\
\hline $1992-93$ & 50 & 133.48 & 121.00 & 906.50 & 17.42 & 6.98 & 439 & 1590.00 \\
\hline 1993-94 & 50 & 134.82 & 1778.00 & 1320.28 & 33.39 & 134.37 & 496 & 2695.00 \\
\hline 1995 & 54 & 154.00 & 209.00 & 1441.38 & 46.30 & 17.18 & 482 & 3564.00 \\
\hline 1996 & 56 & 150.58 & 204.00 & 1354.76 & 36.82 & 13.41 & 492 & 2726.00 \\
\hline 1997 & 56 & 150.58 & 128.73 & 854.90 & 29.02 & 11.23 & 480 & 2340.00 \\
\hline 1998 & 56 & 149.65 & 137.44 & 918.48 & 37.34 & 14.79 & 619 & 2389.00 \\
\hline 1999 & 56 & 149.65 & 147.00 & 982.30 & 40.29 & 15.98 & 615 & 2598.00 \\
\hline 2000 & 54 & 151.79 & 161.20 & 1062.00 & 47.59 & 17.70 & 636 & 2783.00 \\
\hline 2001 & 52 & 144.8 & 187.18 & 1292.7 & 54.07 & 20.66 & 666 & 3102 \\
\hline 2002 & 52 & 153.8 & 201.00 & 1304.65 & 55.95 & 22.18 & 722 & 3072 \\
\hline 2003 & 51 & 146.40 & 208.17 & 1421.93 & 56.04 & 22.29 & 776 & 3488 \\
\hline 2004 & 51 & 146.40 & 215.34 & 1470.90 & 60.21 & 23.95 & 873 & 3772 \\
\hline 2005 & 52 & 150.00 & 237.10 & 1580.67 & 68.30 & 27.11 & 942 & 4236 \\
\hline 2006 & 46 & 106.67 & 260.00 & 2437.42 & 92.60 & 33.10 & 1159 & 4911 \\
\hline
\end{tabular}

Source. Grameen Mostsho O pashusampad Foundation Annual Report 2006

\subsection{Jamuna Borrow-Pits Farm (JMBA)}

The Jamuna Borrow Pits were created as result of construction of East and West Approach roads of Jamuna Bridge in Tangail and Sirajgong. Due to acquisition of land on both sides of the road, many people were rendered homeless and landless. The people are called Project Affected Person s (PAPs). Jamuna Multipurpose Bridge Authority (JMBA) has its moral and legal responsibility to $42 \mathrm{~km}$ of slopes of the approach roads for construction of ponds for fish culture and developing the farms for agriculture and horticulture and the slopes for plantation. GMPF accepted the offer from the government for fish culture in the ponds and plantation besides the road and took over possession in 1997 by virtue of agreement for 25 years lease singed between Jumuna Multipurpose Bridge Authority (JMBA) and GMPF on 12-03-1997. Under this project the major component was excavation of 90 ha of new water areas (ponds) for creating physical resources for the poor people living adjacent to the $42 \mathrm{~km}$ long East and West approach Roads of the Jamuna Multipurpose Bridge (JMB) in Tagnail and Sirajgonj districts. During 1998-2004 only 65 ponds having a water area of 67 ha were excavated under JBPF. This project is a unique example of Integrated Farming through Fish-Crop-Livestock and Social Afforestation having 1005 women VGMs-the only one of its type in Bangladesh.

\subsection{Chokoria Shrimp Farm}

GPF has also been executing shrimp farm named Chokoria Shrimp Farm at Chokoria sub-district in Cox's Bazar district. This farm was handed over by Department of Fisheries (DoF) to GMPF in 1986 for 25 years on lease. It has area of 300 acres of water area and producing shrimps since inception. In 1992-1993 semi-intensive shrimp culture was started in 42 ponds. From 1996 the farm did not culture any intensive semi-intensive shrimp but traditional extensive shrimp culture was re-introduced to get rid of the diseases problem. The farm had one dairy farm with 49 cows/cattle and it has over 1911 coconut trees. It produced 19.26 MT shrimps and 6.47 MT 
Rouf, K. A.

fish in 1996 (Grameen Mostsho O Pashusampad Foundation Annual Report, 2006).

Table 3

Group formation, Centers, VGMs, Ponds and Water Areas

\begin{tabular}{lll}
\hline Activities & Total & Comments \\
\hline No of Centers & 45 & \\
No of Groups & 274 & \\
No of Members & 1259 & $100 \%$ women \\
No of Ponds & 65 & \\
Water Area (ha) & 69.60 & \\
Fish Production (MT) & 52.84 & \\
\hline Source. Grameen Mostsho O Pashusampad Foundation Annual Report 2006
\end{tabular}

\subsection{GMPF Micro-credit Implementation Project}

Grameen Motsho O Pashu Sampad Foundation (GMPF) has been executing the Command Area Development Project and Micro-credit Implementation Project funded by Asian Development Bank (ADB). This project was operated in three sub-districts (Santhia, Bera, Sujanagar) of Pabna district. GMPF had been organizing the ponds, borrow-pits, and irrigation canals of Pabna Irrigation and Rural Development project. The project owners' preferably landless poor, marginal farmers, fishermen, hatchery/nursery operators, net makers, and sellers and other aquaculture related persons. GMPF had organised 499 groups of 5005 beneficiaries, and gave them training in fish culture, gender issues, social development issues, legal awareness etc. It covers 134 villages, and 519 hectors of water areas. The project gave micro-credit to the beneficiaries not in the form of 'cash' but in the form of 'input'. During the project period the project disbursed Tk. 17.05 million as input credit to the beneficiaries and the recovery rate is $86.30 \%$.

Table 4

No. of groups, no. of beneficiaries, fish cultivation areas, loan disbursement, savings collections

\begin{tabular}{llllllll}
\hline $\begin{array}{c}\text { Descripti } \\
\text { on }\end{array}$ & $\begin{array}{c}\text { \# of } \\
\text { group }\end{array}$ & $\begin{array}{c}\text { \# of } \\
\text { beneficiaries }\end{array}$ & $\begin{array}{c}\text { Area under } \\
\text { cultivation }\end{array}$ & $\begin{array}{c}\text { \# of } \\
\text { villages } \\
\text { covered }\end{array}$ & $\begin{array}{c}\text { Savings } \\
\text { collections } \\
\text { million in } \\
\text { (TK.) }\end{array}$ & $\begin{array}{c}\text { Loan } \\
\text { disbursement } \\
\text { in million in } \\
(\mathrm{TK} .)\end{array}$ & $\begin{array}{c}\text { Loan } \\
\text { recovery in } \\
\text { million } \\
\text { (TK.) }\end{array}$ \\
\hline Actual & 341 & 3553 & 367 & 126 & 7.93 & 17.05 & 118.94 \\
Target & 341 & 3410 & 341 & 126 & - & 17.05 & 14.50 \\
$\%$ & $100 \%$ & $104.2 \%$ & $107.6 \%$ & $100 \%$ & - & $100 \%$ & $81.37 \%$ \\
\hline
\end{tabular}

Source. Grameen Mostsho O pashusampad Foundation Annual Report 2006

\subsection{Empowerment of Coastal Fishing Community for Livelihood Security Project (ECFC)}

Grameen Mossho O Pashu Sampad Foundation (GMPF) was executed the social mobilization program 'the Empowerment of Coastal Fishing Communities and Livelihood Security Project' (ECFC) in Cox's Bazar, Ramu, Teknaf, Ukiya, Moheskhali and Kutubdisa sub-districts under Cox's Bazar district covering 65 fishing villages, and 149 village organizations. This project was basically a social mobilization and community empowerment project following a multidimensional approach. The project engages a numbers of service providers from the private sector to assist the project in achieving its objectives within the framework of project concept, strategy, and institutional arrangements. The developmental objectives of the project were to promote livelihood security of the poor coastal fishing communities. The ECFC immediate objectives were to: (1) assist the communities to empower themselves to collectively address their problems and needs; (2) introduce various economic and community approaches which are operated and managed by the community organizations; and (3) facilities sustainable conservation and management of coastal marine and estuarine fisheries resources and habitats through strengthening of community based management of the resources. ECFC target people are marginalized women, children and men are from the coastal fishing communities and the people who are most prone to 
recurrent natural disasters.

The project concept is based on the Sustainable Livelihood Approach-includes the vulnerability context, peoples coping and adaptive strategies, the livelihood assets, and the livelihood outcomes. Poor fishing communities have access to information, assets and resources as well as knowledge and technologies, employments and alternative income options in the area. ECFC emphasizes on marine fishing technologies and strength capacity building for disaster management among coastal people.

\subsection{Community Livestock and Diary Development Project (CLDDP)}

The objectives of the CLDDP project are to contribute to national efforts for poverty alleviation by providing a model for sustainable rural development opportunities for women. The project is located in GMPF`s three-existing farm areas namely (1) Joysagar Farm, (2) Dinajpur Farm, and (3) Jamuna Borrow-Pits Farm (JBPF) in 18 sub-districts of 7 districts in Northern West of Bangladesh. CLDPP works in 375 villages of 18 sub-districts of seven districts in Bangladesh. It has 360 centers, 1150 groups and 7750 beneficiaries where 4600 were male (59.35\%) and 3150 females (40.65\%) under 22 GMPF unit offices (Grameen Mostsho O Pashusampad Foundation Annual Report 2006). The following table shows GMPF meat, milk, dung and eggs production of GMPF under CLDDP.

\section{Table 5}

Production of Milk, Meat, Cow Dung and Eggs

\begin{tabular}{ll}
\hline Produces & Total (as of 2006) \\
\hline Total Milk Production (Liter & 6723871 \\
Milk received by CDE (Liter) & 3560999 \\
Eat (Fattening Cattle) (MT) & 1478.99 \\
Cow dung: produced (MT) (Estimated & 62434 \\
Egg (nos) & 1329591 \\
\hline Source. Grameen Mostsho O Pashusampad Foundation Annual Report 2006
\end{tabular}

\section{Livestock Development Fund (LDF)}

A savings account has been opened at each of the GMPF village centers to make up a local Livestock Development Fund by VGMs. Each VGM contributes TK. 5 at every fortnightly meeting as a compulsory savings into the LDF. This is considered to be a personal savings of each VGM and proper records were maintained at the center to determine the amounts saved by each VGM so that he/ she may be able to withdraw the full amount with interest at the time the VGM leaves the center. Every time a VGM receives a loan for a livestock package through the center, a sum equal to $2.5 \%$ of the value of the livestock (milk cow and pregnant heifer) procured is deducted from the total loan amount and deposited into the LDF at the centre. When the group repays the loan capital and interest at the fortnightly meeting of the center, $25 \%$ of the interest is deposited into the DF account. Each VGM is expected to contribute to the LDF at the rate of thirty paisa (TK. 0.30) for every liter of milk sold, irrespective of whether it is sold direct to the market or through the Community Dairy Enterprise (Grameen Mostsho O Pashu Sampad Foundation Annual Report, 2006). Bank interest for the fund accrued in the savings account gets added every quarter into the LDF. Any fine imposed by the centre on the GM is also deposited into the LDF.

\section{Livestock Insurance Fund (LIF)}

$2.5 \%$ of the purchased value of cows/heifers realized as premium have been deposited to the insurance account. Out of 5445 cow heifer 177 died and compensation paid against 148 dead cow heifers. The details of livestock insurance fund position are shown in Table below. 
Rouf, K. A.

\section{Table 6}

Insurance Fund: Premium and Compensation

\begin{tabular}{ll}
\hline Description & Total \\
\hline No. Of insured cows heifers & 4250 \\
Total premium realized (Tk.) & $27,21,809$ \\
No. Of insured cows heifers died & 177 \\
No. of Insurance claimed settled & 148 \\
Amount of insurance claimed settled & $3,79,170$ \\
Total LIF & $31,05,554$ \\
\hline Source. Grameen Mostsho O Pashusampad Foundation Annual Report 2006
\end{tabular}

Source. Grameen Mostsho O Pashusampad Foundation Annual Report 2006

\section{Livestock Support Services}

The project provided adequate facilities for treatment, vaccination, artificial insemination, fodder cultivation and pregnancy test for cow heifers. Moreover facilities like treatment, vaccination and other facilities for goats, poultry, ducks etc. provided with necessary equipment, instruments, trevice, LFA kit box and other ancillary appliances. In addition, linkage has been established with Department of Livestock Services (DLS) to provide more necessary inputs and veterinary services.

\subsection{Community Livestock Centers and Livestock Sub-centers}

In order to provide needed veterinary services for the livestock distributed to the VGMs, the project has set up 6 Community Livestock Centers (CLC) at Nimghachi, Tarash, Sujan, Elenga, Ramrai and Dinajpur. Moreover five livestock sub-centers setup at Nandigram, Nalka, Deul, Vitargarh, Belowa and Ramarai units. Eighty-five service points had been equipped with all veterinary facilities including mini laboratory. They had been managed by a Community Livestock Officer (CLO), Livestock Field Assistant (LA) and Veterinary Compounder (VC) located at the SC. The CLO, LFA VCs services are given free of cost. If the livestock is owned by a non VGM the cost of medicine, vaccine, artificial insemination and emergency call fees are realized and deposited into a Livestock Services Fund maintained at the respective farm. Required number of community members also given training on AI techniques by DLS for a period of 3-months. These trained personnel earned money by insemination privately. The following table shows scenario of the treatments, vaccinations of cattle, poultry and ducks and artificial insemination and pregnancy test of cow heifers.

Table 7

Livestock, Poultry, Breeding and Treatment

\begin{tabular}{ll}
\hline Description & Total (as of 2006) \\
\hline No. of various types of Vaccination & 114631 \\
Artificial Insemination and Pregnancy Test & \\
No. Of Artificial Insemination done by the project & 7429 \\
No. Of Pregnancy Diagnosis done by DLS & 1665 \\
No. De-worming done by the project & 17103 \\
No. of Infertility treatment done by the project & 1216 \\
Total no. of cases treated at & \\
Trevice Points & 13559 \\
CLC LSC & 13258 \\
VGMs house on emergency call & 960 \\
VGMs houses services provided & 28157 \\
\hline Source. Grameen Mostsho O Pashusampad Foundation Annual Report 2006
\end{tabular}

\subsection{Feed supply and Fodder Cultivation}

The project motivated the VGMs on the advantages of feed and fodder for dairy cows setting up demonstration plots in Units. Distribution of milch cow was subject to a condition that every VGM should plant at least a small plot of improved grass such as Napier, Guinea grass, maize or ipil-ipil whatever land available in 
the backyard of the beneficiaries or on pond embankments. Grass cutting and ipil-ipil seedlings were distributed to the VGMs. VGMs cultivated 1396 decimal napier plots , 125 decimal guinea plots, 6.03 decimal ipil-ipil plots and 445 decimal maize plots and others 700 decimal. The project has also set up feed mills for supplying quality cattle feed to the VGMs. Since inception 3 feed mills produced and distributed 5184 Metric tons of feed (Grameen Mostsho O Pashusampad Foundation Annual Report 2006).

\subsection{Community Feed Mill (CFM)}

Although there is a provision for two feed mills at Nimgachi and Dinajpur, the project established three feed mills one more at JBPF for facilitating steady supply of quality feed to the VGMs. All the feed mills are functioning well with highly satisfactory management and producing quality cattle feed by producing raw materials from the local market and mills. Feed samples of collected ingredients are sent to nutrition laboratory of DLS in every six- months. The results compare well with national analytical figure. Moreover, feedback information from VGMs about feed is also promising. The price of feed is fixed by the committee and their selling price varies depending on their price of ingredients. A profit margin of TK. 0.50-1.00 is kept in the Feed Mills account to build up working capital. The feed mills are jointly owned and managed by the Community and GMPF with 70:30 share of profit. Feed mills employ managers and staffs from the community only.

\subsection{Community Dairy Enterprise (CDE)}

Two Community Dairy Enterprises (CDs) with milk cooling tanks of 2000 liter each were established at Nimgachi and Dinajpur. Under changed situation and market demand more facilities had been developed in 3 farm areas for preservation and marketing of milk. Beyond 2 cooling tanks of 2000 liter capacity each set up at Joysagar and Dinajpur 8 more cooling tanks of 2000 liter capacity and 1000 liter capacity have been set up at Nalka, Nandigram, Tarash, Belwa and Ramrai. Total cooling capacity of milk was 16,000 liters per day (Nimgachi 4000, Tarash-3000, Nandigram-2000, Nalkas-2000, Belowa-1000, Dinajpur-1000 and Ramrai-3000 liter) (Grameen Mostsho O Pashusampad Foundation Annual Report, 2006).

\section{Conclusion}

GMPF employed local people to work in the GMPF fish culture firm and livestock farm. GMPF mobilise local villagers to make fish culture associations and let them jointly (association members and GMPF field staff) work with the project in order to increase livestock and fish production in the area. GMPF livestock association members benefited from the GMPF services. It has setup milk collection chilling points at different locations near to villages where people sell their milk. The Grameen Yogurt plant uses the collected milk for producing Grameen Yogurt. Many local people employed in this Yogurt plant for producing and selling yogurt.

Modern fish culture and livestock production technologies were introduced to the project. GMPF conducted many workshops on livestock management, fish culture management, community forestation and micro-credit for local people that have impacted increasing local fish and livestock production and community forestation. Many NGOs' field workers, government officials and international agencies visited the project and learn GMPF activities and management strategies. For example, Bangladesh Fisheries Development Corporation, DFID, UK, JICA, Indian Livestock Association, Nepal Fisheries Department, Kenya Livestock Department etc. visited GMPF and they learned about GMPF ponds management.

The author finds GMPF beneficiaries gain access to modern livestock and fish production through this project that resulted in an increase to their income, created excitement, confidence, access to better food, housing and social activities, acquire new skills and information and developed coping strategies through GMPF. The GMPF technology transfer process helps local poor to develop their leadership skills, exposed to technologies on modern fish culture, and livestock production and community forestation. GMPF these activities, programs and services have created many employments in project area and help the community to be self-help at the local level. 
Grameen Bank field staff works hard to serve local poor people in providing micro loans, open center schools cost free for the poor in addition to other benevolent activities in Bangladesh. GBJMP has developed a people centered decentralised local community partnership ponds management model for low cost fish culture and livestock production in the project area that become an examples for the local communities and other agencies in Bangladesh. The author and his GB staff extend their full cooperation to GBJMF in order to run the ponds smoothly under GBJMP management. All people were impressed of GB and GBJMF activities. The author narrated his GB and GBJMP working experiences in his monthly official report received from the project during his tenure at Nimgashi. It was a great experience for him.

The Khas ponds lease agreement between Grameen Bank and GoB was for 25 years (1986-2010). The Government of Bangladesh did not extend the lease period; hence GMPF returned all these Khas ponds to GoB in 2010. Khas ponds return to Government by GMPF has declined community members' access to ponds management and fish cultivation. As a result GMPF association members and beneficiaries are deprived from the pond management participations although they are conscious about their rights to access to Khas ponds fish culture. Hence the sustainability of this GMPF community economic development project faces red tape challenges to develop/flourish. Moreover, there is a question would the government bureaucrats red tape be able to carry people centered GMPF fisheries and livestock associations services to communities because government officials do not have experience working with the local communities in Bangladesh.

\subsection{Implications of the Study}

The experience of GMPF is one of the examples of CED green program in Bangladesh. In theory CED approach has many advantages in producing local jobs creation, increase income among community members, empower people, and address the issue of poverty by using local resources for local community members. It is an approach where private-public-community agencies make partnerships among them and serve to local communities for their wellbeing. GMPF has community Khas ponds project. This community project cultivates fish by employing local poor people. Moreover, GMPF project encourage community members to become involved in fish culture; livestock productions and community forestations in its project area. They are an asset-based community economic development project that has an innovative strategy for community-driven development for rural communities in Bangladesh. Therefore, community economic development workers, researchers, policy makers, academicians and executives could learn from GMPF different services, products, tools and its implementation strategies from this paper. This paper can assist them to plan and to initiate CED projects in their own communities lesions learned from GMPF.

\section{References:}

Alexander, J. (2000). Adaptive strategies of nonprofit human services organizations in an era of devolution and new public management. Nonprofit management and Leadership, 10(3), 287-303. http://dx.doi.org/10.1002/nml.10305

Boothroyd, P., \& Davis, H.G. (1993). Community economic development. Journal of Planning Education and Research, 12, 230-240. http://dx.doi.org/10.1177/0739456X9301200307

Brown, W. A., \& Iverson, J.O. (2004). Exploring strategy and broad structure in nonprofit organizations. Nonprofit and Volunteering Sector Quarterly, 33(3), 377-400. http://dx.doi.org/10.1177/0899764004265428

Dees, J. G. (1998). Enterprising non-profits. Harvard Business Review, Jan.-Feb., 55-67.

Grameeen Bank Annual Report. (1987). Grameen Bank Jaoysagor Project 1986 in Grameen Bank Annual Report (1986). Dhaka: Grameen Bank.

Grameen Mostsho O Pashusampad Foundation Annual Report. (2006). Grameen Mostsho O Pashusampad Foundation Annual Report (Grameen Fisheries and Livestock Foundation) 2006. Dhaka: Grameen Bank.

Lotz, J. (1987). Community Development: A short history. Journal of Community Development, May- June, 
40-46.

Mathieu, A., \& Cunningham, G. (2004). From clients to citizens: Asset-based community development as a strategy for community driven development. Antigonish: Coady International Institute.

Memorandum of Articles and Memorandum of Association (GMF). (1994). Grameen Motsho Foundation Memorandum of Articles and Memorandum of Association. Dhaka: Grameen Bank.

Memorandum of Articles and Memorandum of Association (GMPF) (2003). Grameen Motsho O Pashu Sampad Foundation Memorandum of Articles and Memorandum of Association. Dhaka: Grameen Bank.

Putnam, R. (2000). Bowling alone: The collapse and revival of American community. New Work: Simon and Schuster.

Quarter, J., Mook, L., \& Armstrong, A. (2009). Social economy: A Canadian perspective. Toronto: University of Toronto Press.

Shragge, E. (1997). Community Economic Development: In search of empowerment. Montreal: Black Rose Books.

Yunus, M. (2007). Creating a world without poverty: Social businesses and the future of capitalism. New York: Public Affairs. 
Rouf, K. A. 